\title{
Foreign Direct Investments in the Central \& Eastern Europe Countries and the Economic Crisis
}

\author{
Magdalena Kinga Stawicka
}

Institute of Economics, Wroclaw University of Economics, Poland

Copyright $(\mathcal{C} 2015$ by authors, all rights reserved. Authors agree that this article remains permanently open access under the terms of the Creative Commons Attribution License 4.0 International License

\begin{abstract}
Consequences of the global economic crisis have affected every field of the world economy and the general phenomenon is a complex sequence of interrelated incidents, which has its reasons and effects as well. The recession, which started in 2007, has affected both, an amount and a form of capital flows. Aim of this paper is analysis of impact of the recent economic crisis on a stream of the foreign direct investments, with special attention paid to the Central \& Eastern Europe countries.
\end{abstract}

Keywords FDI, Economic Crisis, Central \& Eastern Europe

\section{Introduction}

From 2008 to 2009 the world economy suffered from the deepest economic crisis since 30's of the twentieth century. It is worth of mentioning that the crisis surprised both, entrepreneurs, authorities, practitioners but also those, who deal with economics in the field of theory. Generally it is considered it was a resultant of three factors ${ }^{1}$ : too expansive monetary policy applied by the FED, too large creation of complicated financial instruments characterized by blurred responsibility as well as wrong governmental regulations on the mortgage loans market. Too large investments on the American real estate market as well as no solvency of mortgage loan recipients resulted in a recession in the credit market (credit crunch). The crisis, at the very beginning observed in a single sector of the American economy, was expanding quickly and affected nearly the entire economy of the USA and then, the world economy. It also very severely struck growing markets and members of the European Union as well as the remaining European countries.

Despite effects of the crisis have been suffered by the

1 Detailed reasons of the economic crisis were described by, among others, W. Szymański in his Kryzys globalny. Pierwsze przyblizenie (Global crisis. First view). Difin, Warsaw 2009, p. 13-118. financial sector, one of negative effects was weakening of the globalization process and process of regional integration in a real field. Decrease in consumption and investments caused decrease in dynamics of the international trade as well as the foreign direct investments worldwide. Enterprises focused on saving of financial means in order to re-pay their growing debt instead of their development, including expansion into foreign markets and investments. Therefore, a new trend caused that capital flows were seriously reduced by the world financial crisis.

Aim of this paper is presentation of capital flows in the Central \& Eastern Europe countries ${ }^{2}$ in the context of the world economic crisis.

\section{What Is the FDI and Why Is Important for Central \& Eastern Europe Countries}

The definition of the FDI, used by central banks to compile balance of payment statistics is prescribed by the IMF's Balance of Payment Manual 1993 [1]. According to this source, "direct investment is the category of international investment that reflects the objective of obtaining a lasting interest by a resident entity in one economy in an enterprise entity in another economy... (it)... comprises not only the initial transaction but also all subsequent transactions between affiliated enterprises". This definition divides the FDI into equity capital, reinvested earnings and other capital associated with inter-company debt transactions. The FDI is distinguished from portfolio investment by the influence that gives direct investor an effective voice in management.

To explain the difference in the FDI performance among countries, it is necessary to understand how foreign investors choose their investment locations. The FDI

2 Acc. to OECD's definition region of the Central \& Eastern Europe comprises the following countries: Albania, Bulgaria, Croatia, Czech Republic, Estonia, Lithuania, Latvia, Poland, Romania, Slovakia, Slovenia, Hungary. In other Polish and foreign publications this region includes also Bosnia and Herzegovina, Kosovo, Macedonia, Montenegro, Serbia, as well as Belarus, Moldova, Ukraine and Russia. 
usually goes to the countries where it is possible to combine the ownership advantages with the location specific advantages of the host countries through internationalization advantages of foreign investments [2]. In the subject-matter literature there are very different divisions of direct investments theories. The most common categorization is the one proposed by J. Misala [3] into microeconomic, macroeconomic and mixed theories for direct investments.

Among microeconomic theories there are:

- portfolio investments theory

- theory of investment portfolio diversification,

- enterprises' behavior theory

- theory of reaction of enterprises to oligopolistic conditions for competition.

- theory of financial liquidity for a foreign subsidiary

- theory of possession (related) advantage of an enterprise,

- theory of internal transactions,

- theory of appropriation (capability).

Among macroeconomic theories there are:

- theory of the capital profitability,

- theory of foreign manufacture volume and absorptive of foreign markets,

- theory of monetary areas,

- theory of relative distribution of workforce and capital costs,

- theory of shaping investment advantage on foreign markets.

Mixed theories enumerated by J. Misala contain:

- localization theory for foreign direct investments,

- eclectic theory of international manufacture.

Generally, the internationalization is a process of increased commitment of an enterprise to international economic activity including both, passive (import, license purchase) and active (e.g. export, FDI) forms of entity internationalization. Because of significance of the internationalization process at the level of domestic economies (macroeconomic level) and at the level of particular enterprises (microeconomic level) in the contemporary economic conditions, this issue has been for a long time main subject-matter of general economics including sciences dealing with the management field. General concept of internationalization of economy and enterprises is also based on scientific researches focused on a multi-dimensional globalization phenomenon [4].

Researchers of transformation processes in the Central \& Eastern Europe are more and more aware of the fact that direct foreign investments determine operations of economic entities and their efforts made to implement their strategies and development of a competitive strategy. Radical changes, which took place in the Central \& Eastern Europe started at the beginning of 90 's, and which have not been completed yet, are called fundamental and overall changes of formal and informal procedures having an impact on operations of units. For these reason economies of the transformation period constitute an interesting subject-matter of researches. At the beginning of 90's there were implemented new formal institutions and there was altered environment of economic activity because of transformation from socialist economy into the market economy. Numerous concepts, e.g. [5], [6] emphasize that advantages of regions arising from locations make they become attractive for foreign investors. At the very beginning it was considered they comprise costs of labor of efficiency of labor. Recently, more and more frequently there have been mentioned know-how, infrastructure or afore-mentioned institutions [7]. Consequently, the institutional environment has been growing as an important competitive advantage. Apart from formal institutions, international attractiveness of a location is affected (determined) by legal, political and administrative systems. Institutions themselves affect operation capabilities of companies on a particular market, having an impact on relative costs of transactions and coordination of production and innovation [8]. Hence, investors look for such locations, where institutional area enables development of their advantages worldwide and which make new opportunities for international companies and for an economic policy [9].

In the Central \& Eastern, serious changes at the transformation stage were intended to replace the centrally planned economy with a free market. The processes in question have been taking place at very varied intensiveness and efficiency in particular economies. In Peng's opinion [10] transformation of institutions in such economies is much more effective than all informal changes. Foreign investors, who operate on these markets at the beginning of 90 's had to adjust their operations and strategies to local institutions. For sure, western investors, who started their business in Central \& Eastern countries, had to face higher transactional costs compared to costs on developed markets since transformation is a source of temporary non-completeness of institutional frames. These costs were much more diverse among countries since adjustment process took place at varied tempo and to a varied extent.

In the literature on the subject, many researchers deals with the issue of motives and barriers of investments. Several surveys and researches have been conducted to verify theses and show new tendencies regarding the analyzed phenomenon.

In 1996, Institut der Deutschen Wirtschaft was commissioned by Bundesverbad der Deutschen Industrie and Ost-Aussuß der Deutschen Wirtschaft to conduct survey research in which German respondents were asked to enumerate motives and barriers for investment in Central and Eastern Europe [11]. The most significant motives given by the respondents for their business activities in their respective areas were: creating new markets for their products, certainty of potential markets (big chances to succeed on a new market), low labor costs, certainty of existing markets and taking care of them as well as strengthening of competitive position through foreign 
manufacturing. Among the main concerns related to the said investments, the respondents specified (in the following order) unstable law regulations, the state's strong influence on companies' economic environment, remnants of centrally planned economy, bad conditions for performing business activities (complex and intricate law regulations and bureaucracy), low levels of productivity and lack of support from the authorities.

Another research on the determinants for direct foreign investments was carried out by Nunnenkamp and Spatz [12], who used 28 emerging countries between 1987 and 2000 as a sample and determined a strong relationship between the value of direct foreign investment and such indices as GDP per capita, investment risk index, levels of education in respective societies, restrictions on foreign trade, law regulations for the labor market or labor costs in the respective countries. It turned out that such factors as population, economic growth, entry/exit barriers and technological regulations of manufacturing are of no importance when decisions are taken by foreign business in relation to investing their capital in emerging markets. However, between 1977 and 2000, a significant influence of manufacturing costs as a decisive factor for choosing a location for investment was noticed in the researched countries.

Holland, Sass, Benacek and Gronicki [13] analyzed the literature on the subject connected with the factors decisive for an influx of direct foreign investment to the countries of the Central and Eastern Europe and came with a conclusion that decisive factors are the size of the market and development perspectives for the country. Campos and Kinoshita (2003) analyzed 25 transforming economies of the region in 1990-1998 and concluded that the following factors play a decisive role in acquisition of foreign capital: type of economic system, size of the market, low labor costs and abundance of natural resources. In addition, other important determinants listed by these authors were: level of the country's openness for foreign trade, no bureaucracy - existence of so-called ,healthy institutions" and friendly pro-investment policy for foreign capital, which result in low barriers for starting business activities or investing financial assets. Similar research to Campos's and Kinoshita's [14] was carried out by Garibaldi, Mora, Sahay and Zettelmeyer [15] who analyzed 26 transforming economies between 1990-1999 using an array of substantial variables. The analyzed macroeconomic factors were structural reforms, legal and institutional frameworks, terms \& conditions of establishing of a business and investment risk in those countries. In the conclusions, it might be noticed that all of such macroeconomic variables as the size of the market, budget deficit, inflation rate, political system, extent of investment risk, implemented economic reform, economy's openness to foreign trade, availability of natural resources, investment barriers and bureaucracy, play a key role in decision making on investment by foreign business entities.

In their analyses, apart from traditional factors such as: market potential, labor cost and the availability of skilled labor, Carstennsen and Toubal [16] took into account the level and methods of privatization. Market size and agglomeration effects are key determinants for French multinationals investigated in Disdier and Mayer [17] but differences between investments in Eastern and Western Europe are attributed to the quality of institutions in the host country. They examined bilateral flows from individual source countries to the host countries in Central and Eastern Europe. Unit labor cost, as well as host and source country size and proximity turn out to be significant, so they conclude that both market-seeking and efficiency-seeking investments are taking place.

\section{Global Crisis and Economic Situation of the Central and Eastern Europe Countries}

The economic crisis, already mentioned in the preface, started in the banking and financial sphere and then, similarly to "domino effect" it has expanded into the real sphere of world economies. Extent of relations among countries resulting from an ongoing process of globalization and internationalization highlighted issues related to the financing of business in other countries. Analysis of macroeconomic factors (see table 1) in the period preceding the economic crisis did not enable to make a clear forecast such a negative phenomenon was going to take place. Selecting basic criteria to assess the economic situation of regions under examination and the United States of America one may observe a clear decrease in real gross domestic product and export volume. Additionally, negative impact of the crisis is reflected by a public debt compared to the gross domestic product as well as related budget deficit in relation to the gross domestic product. In case of member countries of the European Union a real hazard appeared for the integration mechanism because of growth of the public debt in the economies exceeding the criteria for the convergence. High growth of the public debt caused that at the European Union level an excessive deficit procedure (EDP) was commenced, intended to obligate governments to implement relevant corrective actions. No corrective actions could result in financial sanctions even if a country had already suffered from financial problems. Heavy growth of the index was also observed in case of the unemployment rate which went up, during one year, from $2.1 \%$ in member countries of the European Union up to $3.4 \%$ in the region of the Central \& Eastern Europe countries. 
Table 1. Macroeconomic situation in USA and selected regions, 2006 - 2010 (in \%)

\begin{tabular}{|c|c|c|c|c|c|}
\hline Specification & 2006 & 2007 & 2008 & 2009 & 2010 \\
\hline \multicolumn{6}{|c|}{ Real GDP growth } \\
\hline Central \& Eastern Europe & 6.4 & 5.5 & 3.1 & -3.6 & 4.5 \\
\hline European Union & 3.6 & 3.3 & 0.7 & -4.2 & 1.8 \\
\hline USA & 2.7 & 1.9 & 0.1 & -3.5 & 3.0 \\
\hline \multicolumn{6}{|c|}{ General government net lending/borrowing } \\
\hline Central \& Eastern Europe & -1.7 & -1.0 & -2.8 & -5.7 & -5.4 \\
\hline European Union & -1.4 & -0.8 & -2.3 & -6.8 & -6.4 \\
\hline USA & -2.0 & -2.7 & -6.5 & -12.7 & -10.6 \\
\hline \multicolumn{6}{|c|}{ General government gross debt } \\
\hline Central \& Eastern Europe & 30.2 & 28.5 & 29.6 & 36.8 & 40.8 \\
\hline European Union & 61.5 & 59.4 & 63.7 & 73.9 & 79.5 \\
\hline USA & 61.1 & 62.2 & 71.2 & 84.6 & 91.5 \\
\hline \multicolumn{6}{|c|}{ Unemployment rate } \\
\hline Central \& Eastern Europe & 8.7 & 7.3 & 6.8 & 10.2 & 11.9 \\
\hline European Union & 8.2 & 7.2 & 7.8 & 9.9 & 9.5 \\
\hline USA & 4.6 & 4.6 & 5.8 & 9.3 & 9.6 \\
\hline \multicolumn{6}{|c|}{ Export volume of goods and services } \\
\hline Central \& Eastern Europe & 11.3 & 11.5 & 7.0 & -10.8 & 11.8 \\
\hline European Union & 8.8 & 6.5 & 0.4 & -14.3 & 11.5 \\
\hline USA & 9.0 & 9.3 & 6.0 & -9.5 & 11.8 \\
\hline
\end{tabular}

Source: own work based on the IMF's data - www.imf.org (as of 02.07.2015)

The economic crisis struck countries of the European Union and Central \& Eastern Europe to a varied extent, however, worsen macroeconomic indexes were observed in every country ${ }^{3}$ Comparing extent of the recession one may notice that in 2009 it was clear the stagnation occurred in the most of the developed European Union member countries. And so, Finland suffered from the GDP fall exceeding $8 \%$, Ireland $-7.7 \%$, and Italy $-5.2 \%$. Among the countries of the Central and Eastern Europe 18\% decrease in the GDP was observed in Latvia, $14 \%$ in Lithuania and $8 \%$ in Slovenia. The only one economy, which noted an economic growth, was Poland, GDP of which was estimated (year to year) approx. 1.65\%. The already mentioned worse situation in the public finances sector from 2008 to 2010 is clearly demonstrated in the table no. 1. Budget deficit index in the USA equaled $12.7 \%$ in 2009 and it was a little bit better in 2010. Very slight positive changes were observed in the Europe Union countries and the Central \& Eastern Europe countries. Although the budget deficit average in relation to the GDP was smaller nearly by half compared to the USA, still analysis of particular economies shows less positive picture. Lithuania reached $9.2 \%$ of the budget deficit index in 2009 and in many countries the index in question exceeded $7 \%$. Bulgaria is an exception. In 2008 it still had a budget surplus equal $2.4 \%$ and in 2009 it suffered from a deficit equal to $0.4 \%$. Among the European Union member countries the highest deficit index was observed in the Ireland $-32.4 \%$ and Greece $10.5 \%$. Growth of the budget deficit and troubles of the

3 One should remember that many countries of the European Union are also classified as countries of the Central \& Eastern Europe. world economy caused governments had to fall in debts. At the same time, the public debt index in USA and the EU's countries and countries of the Central and Eastern Europe grew up seriously. In 2009 for USA it equaled $84.6 \%$ of the GDP while a year later it exceeded $90 \%$. Average for the European Union is also very high and it exceeds the $60 \%$ limit established in form of the Maastricht Treaty. Such a high index was reached as a result of enormous debt of the Greek economy (exceeding 125\%) and maintenance of high level of the public debt by Italian and Belgian economies (approx. 100\%) since they had joined the European Union. Luxembourg was the sole exception which means the index in question went up, however, its initial level equal to $6.6 \%$ and alteration up to $14 \%$ finally also contributed to a decreased average for the entire group. Central \& Eastern Europe, from 2006 to 2010, was characterized by a relatively low debt level. As a result of the world crisis value of the index went up, however, in 2009 it equaled just half of the index reached by the Union's countries together. The highest public debt index was observed in Hungary (78\% of the GDP), and the lowest one in Estonia - just 7\% of the GDP.

Most of countries under examination suffered from decrease in the export \& import volume as a result of the economic crisis. Countries, where export contributes to the domestic product to a large extent, were very exposed to effects of the crisis meaning decrease in trade (e.g. Austria, Belgium, Holland). The following year situation was stabilized with a few exceptions: Bulgaria and Portugal, where the negative trend maintained also in 2010.

Data demonstrated in the table no. 1 concerning the crisis 2010 brought some information and a hope that the crisis in 
the world and in the countries under examination had ended and a prosperity was coming. Such a situation lasted to the first half of 2011; in the second half of the year the economy slowed down in many countries again, including the European Union and the Central \& Eastern Europe countries. A factor, which accelerated the boom after the first stage of the global crisis in the Central \& Eastern Europe countries, was export. Just in 2011 annual dynamics of the export for this region exceeded $15 \%$ but the following year it went down up to $2.6 \%$. In 2012 all countries of the Central \& Eastern Europe were characterized by falling dynamics of the export and in case of Bulgaria and Romania even negative values were observed. The situation was an effect of decrease in demand caused by the recession suffered by recipients of goods originating from the Central \& Eastern Europe. The export volume was reduced mostly to, among others, countries of the Euro zone, including Germany which is main recipient of goods and services offered by the region, but also to such countries which still did not belong to the Euro zone. Apart from decreased demand in markets of main partners, having an impact on decrease in the export, the region was exposed to risk of restrictive credit action from local and foreign banks as well as smaller capital inflow from the Western Europe and consequent fall of investments which could promote development of the countries of the region. Additional factors, which hampered growth of the domestic demand, was continuation of public finances consolidation and stagnation on the employment market. Process of the debt reduction in the public sector also had its impact on the situation.

2013 could be considered to be a critical one since in the first quarter of it the GDP in region went up by $0.2 \%$. Accelerated dynamics of the GDP could be recorded in a few countries of the region that is Latvia, Lithuania and Romania. In Croatia and Hungary no economic growth was recorded but lower tempo of its decrease was observed.

Table 2. GDP of the Central \& Eastern Europe, 2011-2015 (in \%)

\begin{tabular}{|c|c|c|c|c|c|}
\hline Specification & 2011 & 2012 & 2013 & 2014 & $\begin{array}{c}2015^{*} \\
\text { (forecast) }\end{array}$ \\
\hline $\begin{array}{c}\text { Central \& } \\
\text { Eastern Europe }\end{array}$ & 3.1 & 0.7 & 2.4 & 3.1 & 1.8 \\
\hline
\end{tabular}

Source: own work based on Global Finance's data - www.gfmag.com (as of 03.07.2015)

2014 was a continuation without any positive changes in the region which could let one to talk about a recovery. Annual GDP growth in the entire region equaled 3.1\% compared to $2.4 \%$ in 2013. Compared to EU-15 countries it was two times higher and among the most quickly growing countries there were Poland, Slovakia and Hungary. Once again it turned out that the domestic demand is one of the most substantial growth factors as it was in case of the Polish economy - the only one, which managed to avoid recession in 2009. Growth in the domestic demand in the region was supported by less restrictive fiscal policy of the governments as well as an accommodative fiscal policy which supported efforts of the economies to overcome the recession.

In the employment market, after the end of the first stage of the crisis, in 2010 and 2011 no serious improvement was observed. Despite the unemployment rate in Estonia and in Latvia went down seriously, still it was very high in Europe. Moreover, in many economies the rate was still growing up. In this period, the employment rate in the Central \& Eastern Europe countries shrunk in nearly every sector which caused low optimism level among consumers and consequently, fall down of the private consumption. Together with increase in the unemployment rate one could observe regularly growing up rate of persons, who had been permanently unemployed as the rate in question rapidly went up in 2012. Again, in case of this rate the crucial year was 2013 when situation in the employment markets in a few countries of the region improved; however, among countries of the Central \& Eastern Europe there were still huge disproportions when it came about dealing with the high number of unemployed persons. The lowest unemployment rate in 2013 characterized Czech Republic and Romania - approx. 7\% while the highest one was observed in Croatia - over 18\% (EUROSTAT, http://ec.europa.eu/eurostat, 03.07.2015). In 2014 situation in the Central \& Eastern Europe countries' employment markets was still improving. In every economy falling unemployment rate was observed, nevertheless, the rate was still high compared to the period before the crisis. Czech Republic and Romania managed to keep the index in question at the 5\%-6\% level while Slovakia and Croatia belonged to countries with the highest unemployment rate accordingly - $13 \%$ and $16 \%$. Improvement in the employment market promoted growth in the employment rate, especially in the retail sale sector, which was also reflected by growing consumption rate. Growth in number of employed persons took place also in other sectors, hence, rate of permanently unemployed persons went down.

Looking at results of the public finances sector in a period from 2011 to 2014 of the Central \& Eastern Europe region one may observe that actions intended to reduce the budget deficit, commenced at the time when the crisis was growing, have been continued in all countries of the region. Namely, for 2011 and for successive years there were established terms to reduce budget deficit up to amount not exceeding $3 \%$ of the budget for European Union countries endeavoring to join the Euro zone. Among them there were Hungary, Bulgaria in 2011, Poland, Romania and Baltic countries with exemption of Estonia (2012), and in 2013 Czech Republic, Slovakia and Slovenia. It made that governments of particular countries focused on reduction on expenses, including freezing of remunerations in administration or pensions \& retirements, and even more social transfers. Politicians hoped that at the moment the situation gets better, entrepreneurs would intensify their market activity and fiscal inflows into the budget would grow up. Moreover, in order to support the public finances consolidation process the Central \& Eastern Europe countries made efforts intended to strengthen institutional 
basis of the public finances sector by implementation of fiscal principles meaning public debt limits or appointment of independent budget advising boards e.g. in Bulgaria, Czech Republic or Slovakia. .

In 2012, terms established to reduce budget deficits based on the excessive deficit procedure - EDP resulted in other adjustment actions implemented by the countries of the region, which were intended to limit expenses of the countries to the largest extent. Most of economies reduced the budget deficit up to below 3\% level with exception of Lithuania and Poland, which exceeded this value slightly accordingly by $0,2 \%$ and $0,9 \%$. Implementation of restrictions in connection with expenses policy of countries of the region resulted in reduced budget deficit the following years. In 2014 just Bulgaria and the EDP-procedure countries that is Croatia, Poland and Slovenia exceeded the $3 \%$ level. Public debt, although the economic situation has improved in the region, went up; when it comes about the Central \& Eastern Europe countries, which belong to the Euro zone, it was caused by an obligation to transfer financial means into the European Stabilization Mechanism (ESM) and European Instrument of Financial Stability. Public debt of the Estonia, Slovenia and Slovakia, as an effect of the afore-mentioned obligation, went up by approx. $2 \%$ of the GDP in 2012 and more than 3\% GDP in 2013.

From forecasts of the National Bank of Poland for 2015 and 2016 the domestic demand will be main driving factor for the economies of the region, but the meaning of foreign demand is still to be weak. The most serious fiscal problems are predicted for Croatia, Hungary and Bulgaria bonds of which were rated "junk" by the largest rating agencies in connection with worsen situation of public finances and a risk the countries in question will become subject of the EDT procedure (FORSAL, www.forsal.pl, 03.07.2015).

To conclude, the world crisis hit the Central \& Eastern Europe region countries to the large extent. Additionally, European Union member countries believed that its effect and, at the same time, a real hazard for the integration mechanism is an increase in the public deficit growth above expected referential values. Previously, optimistic opinions and papers were occurring more frequently; they emphasized that implementation of EUR and establishing of the economic \& currency union assured stabilization of the macroeconomic situation in the member countries [18]. Forecasts and opinions are still not optimistic since more and more frequently economists talk about a risk of next economic crisis which could be even more harmful for the European countries and most of all, for all of the European Union member countries. An evidence of coming recession are problems of Greek economy in the Euro zone.

\section{Economic Crisis and Foreign Direct Investments}

Apart from macroeconomic factors demonstrated in the previous part of the paper, effects of the crisis are also reflected by amount of foreign direct investment streams flowing into the Central \& Eastern Europe region.

Since 70's most of European socialist countries established formal and legal basis for direct capital cooperation with other countries. First regulations regarding foreign investments were established in 1972 in Hungary, later in Poland and Romania (1976), Bulgaria (1980), Czech Republic (1986) and finally - the Soviet Union (1987). In every of above mentioned countries a lot of efforts were made in order to encourage western countries to invest, such as: legal acts, tax releases, possibility to transfer profits and capitals into their genuine countries and so on [19]. Between 80's and 90's it turned out that the historical political change in the Central and Eastern Europe resulted in serious economic crisis. It was caused mainly by an intent to replace economic systems (planned centrally) with the one applied in the Western Europe - capitalism. Restructuring programs caused mass unemployment while opening of the domestic markets for foreign goods resulted in inflow of foreign products and elimination of the domestic ones. Finally, situation of local enterprises became much worse [20]. Despite negative effects of the transformation process the Central and Eastern Europe rejected model of political monolith and the economic model oriented to the economy of the former Soviet Union. Long-term economic relations, agreements, bilateral and multilateral arrangements, priorities and standards were terminated. There came the capitalism. Based on private property and individual initiative, implemented in difficult and unfavorable economic \& market circumstances and social ones. Political system changes and consequent privatization of the national property in this region of Europe made that the foreign investors became interested in cheap market. Under circumstances of general capital deficit on the international money market the European countries' authorities had to encourage foreign partners to invest in Europe. A result was a quick growth in trade volume between so called "Eastern countries" and "Western countries" of the Europe.

From 1985 to 1990 the average annual foreign direct investments inflow into Central and Eastern Europe was equal to $0.3 \%$ of the global FDI flow in the world. Till 1997 the annual increase in the inflow of FDI was observed. It proved growing interest of investors in investments in this part of the world. Subsequent years the share in question was lower and lower but in 2001 it increased again. Increase in the FDI value in the Central and Eastern Europe took place in 2004 which could be result of joining the European Unions by some of the countries. Share of the region in this period in the foreign investments exceeded $5 \%$ and it was the highest rate so far picturing inflow of the FDI into the region in relation to general value of FDI in the world. 
Table 3. Foreign direct investments in the world and in the Central \& Eastern Europe countries 1985 - 2014.

\begin{tabular}{|c|c|c|c|c|}
\hline \multirow{3}{*}{ Years } & World & \multicolumn{3}{|c|}{ Central \& Eastern Europe } \\
\hline & Investments in USD M & \multicolumn{3}{|c|}{ Investments in USD M } \\
\hline & inflow & inflow & Share $\%$ & Change $($ previous year $=100)$ \\
\hline $1985-1990$ & 141930 & 449 & 0.32 & - \\
\hline $1991-1995$ & 221211 & 6679 & 3.02 & - \\
\hline 1996 & 386140 & 9702 & 2.51 & $45 \%$ \\
\hline 1997 & 481911 & 11778 & 2.44 & $21 \%$ \\
\hline 1998 & 686028 & 19250 & 2.81 & $63 \%$ \\
\hline 1999 & 1079083 & 20424 & 1.89 & $6 \%$ \\
\hline 2000 & 1392957 & 22367 & 1.61 & $10 \%$ \\
\hline 2001 & 823825 & 30362 & 2.47 & $-9 \%$ \\
\hline 2002 & 651188 & 24707 & 3.79 & $21 \%$ \\
\hline 2003 & 559576 & 15616 & 2.79 & $-37 \%$ \\
\hline 2004 & 742143 & 38578 & 5.20 & $147 \%$ \\
\hline 2005 & 982593 & 47444 & 4.83 & $23 \%$ \\
\hline 2006 & 1463351 & 65451 & 4.47 & $38 \%$ \\
\hline 2007 & 1975537 & 78099 & 3.95 & $19 \%$ \\
\hline 2008 & 1790706 & 70096 & 3.91 & $-10 \%$ \\
\hline 2009 & 1197824 & 31549 & 2.66 & $-55 \%$ \\
\hline 2010 & 1309001 & 24179 & 1.82 & $-23 \%$ \\
\hline 2011 & 1563749 & 38497 & 2.46 & $59 \%$ \\
\hline 2012 & 1402887 & 43150 & 3.08 & $12 \%$ \\
\hline 2013 & 1467233 & 16971 & 1.16 & $-61 \%$ \\
\hline 2014 & 1228263 & 37036 & 2.02 & $118 \%$ \\
\hline
\end{tabular}

Source: own work based on the World Investment Report for 1991 - 2015.

Since 2003, in countries of the Central \& Eastern Europe region and in the world as well all of the types of investments were characterized by a regular growth trend still observed in the second quarter of 2008. Previous recessions were characterized by the fact that fall of the FDI took place a little bit later then the beginning of a crisis. The delay equaled from 1 to 2 years. Impact of the economic crisis dated 2008 on the world FDI flows was nearly immediate [21]. After the record-breaking level in 2007 the FDI inflow in the world in 2008 was smaller by $9 \%$, however, inflow of the foreign capital into the developed countries went down by as much as $29 \%$. Investments in the European Union countries (EU-27) went down by $40 \%$ and by $48 \%$ into the EU-15 countries.

Table no. 3 shows that in 2008 investments allocated in the Central \& Eastern Europe region shrunk but not so much as in the European Union member countries. It means that in the investors' opinion the growing economies were in much better situation compared to developed countries, which were getting over the beginning of the crisis much worse. The following year, inflow of the foreign investments went down again; transfer of the capital into the region under examination was reduced by more than $50 \%$ compared to 2008 when FDI inflow was lower by $13 \%$. In other words, during every crisis, sectors depending on prosperity suffer seriously. In 2008 the regression was also observed in a processing industry and in some services sectors (such as transport). Industries, which were more resistant to the crisis were those based on a more stable demand - pharmaceutics or basic services.

Among the most frequently enumerated reasons of a decrease in foreign capital in 2008 and in 2009 - apart from the most clear one that is the worldwide crisis - are its effects. Value of international mergers went down. After five year period of a very dynamic growth, number of greenfield investments and so called mega deals went down. Internal financing of companies was additionally limited because of decreased profits and use of external sources of capital. It was more and more difficult to meet criteria for credit and the credit itself was more expensive. Investors, who were observing the crisis, were less susceptible to take a risk what translated into less susceptibility to invest; moreover, weak market perspectives, which translate into sale results of companies, were observed as well. 
Table 4. Inflow of foreign direct investments into the Central \& Eastern Europe countries 2006 - 2014 (millions of USD).

\begin{tabular}{|c|c|c|c|c|c|c|c|c|c|}
\hline Countries & $\mathbf{2 0 0 6}$ & $\mathbf{2 0 0 7}$ & $\mathbf{2 0 0 8}$ & $\mathbf{2 0 0 9}$ & $\mathbf{2 0 1 0}$ & $\mathbf{2 0 1 1}$ & $\mathbf{2 0 1 2}$ & $\mathbf{2 0 1 3}$ & $\mathbf{2 0 1 4}$ \\
\hline AL & 324 & 662 & 988 & 996 & 1051 & 876 & 855 & 1266 & 1093 \\
\hline BG & 7805 & 12389 & 9855 & 3385 & 1525 & 1849 & 1467 & 1920 & 1710 \\
\hline HR & 3457 & 5023 & 6140 & 3077 & 1133 & 1682 & 1451 & 955 & 3451 \\
\hline CZ & 5463 & 10444 & 6451 & 2927 & 6141 & 5405 & 7984 & 3639 & 5909 \\
\hline EE & 1797 & 2716 & 1729 & 1839 & 1540 & 257 & 1569 & 553 & 983 \\
\hline LT & 1817 & 2015 & 1965 & 66 & 753 & 1217 & 700 & 469 & 217 \\
\hline LV & 1663 & 2322 & 1261 & 94 & 379 & 1562 & 1109 & 903 & 474 \\
\hline PL & 19603 & 23561 & 14839 & 12932 & 5558 & 15139 & 7120 & 120 & 13883 \\
\hline RO & 11367 & 9921 & 13909 & 4844 & 2940 & 2670 & 3199 & 3602 & 3234 \\
\hline SK & 4693 & 3581 & 4687 & -6 & 526 & 2143 & 2982 & 591 & 479 \\
\hline SI & 644 & 1514 & 1947 & -653 & 359 & 999 & 339 & -144 & 1564 \\
\hline HU & 6818 & 3951 & 6325 & 2048 & 2274 & 4698 & 14375 & 3097 & 4039 \\
\hline
\end{tabular}

Source: own work based on the World Investment Report for 2009 - 2015.

Detailed geographical analysis of inflow of the foreign direct investments into the Central \& Eastern Europe shows that in the entire region it went down in the first half of 2009. In particular it was observed in Baltic countries. The fall was much lower in Poland. It was connected, most of all, with lower extent of invested profits. In 2010 the downward tendency for the FDI was maintained in most of the countries of the region and investors focused on portfolio investments, in particular, into treasury bonds. The following year situation for the foreign direct investments inflow stabilized and in many countries, including Poland, noticeable growth was observed. In 2012 and 2013 inflow of the FDI into the Central \& Eastern Europe countries went down again. Intra-corporate credits had growing and growing share while role of share investments went down. Nevertheless, fall of the inflow of the foreign capital depended mostly on other investments that is commercial credits and, in the first place, obligations of the financial sector. In 2014 inflow of the FDI grew up and it resulted from growth in their inflow into Poland and Czech Republic and decrease in commitment of portfolio investors.

Dividing the foreign investments into greenfield type, which is the most advantageous form of foreign investments of a country, resulting in erection of a plant in the country, where investment is made, and the brownfield type, that is a merger or taking over of existing company, from 2006 to 2010 there could be observed decrease in number of projects of both types, in the world and in particular countries and regions in 2009.

Table 5. Number of greenfield projects $2006-2010$

\begin{tabular}{|c|c|c|c|c|c|}
\hline & 2006 & 2007 & 2008 & 2009 & 2010 \\
\hline World & 12277 & 12245 & 16422 & 14192 & 14142 \\
\hline EU & 4756 & 4725 & 5578 & 4466 & 4265 \\
\hline CEE & $\mathbf{3 5 4}$ & $\mathbf{2 5 8}$ & $\mathbf{3 2 4}$ & $\mathbf{1 8 2}$ & $\mathbf{2 3 5}$ \\
\hline USA & 748 & 868 & 988 & 1256 & 1470 \\
\hline
\end{tabular}

Source: Author's work based on: World Investment Report 2011. Non-Equity Modes of International Production and Development. UNCTAD, Geneva 2011.

Fall of the number of greenfield projects demonstrated in table no. 5 made in the Union member countries, including Central \& Eastern Europe countries, is for sure an effect of the global crisis but one can guess as well that EU countries became less attractive for foreign investors compared to growing markets. Therefore, there has been observed growth of number of projects in such economies as: China, Singapore, Thailand, Brazil etc. Among the countries of the region under examination the largest number of greenfield investments was carried out in Polish, Croatian, Czech and Hungarian economies. 
Table 6. Number of greenfield projects, 2006 - 2010 in the Central \& Eastern Europe region

\begin{tabular}{|c|c|c|c|c|c|}
\hline & 2006 & 2007 & 2008 & 2009 & 2010 \\
\hline AL & 11 & 8 & 16 & 7 & 6 \\
\hline BG & 6 & 7 & 12 & 4 & 11 \\
\hline HR & 39 & 32 & 40 & 30 & 42 \\
\hline CZ & 41 & 32 & 53 & 12 & 34 \\
\hline EE & 44 & 39 & 26 & 13 & 11 \\
\hline LT & 66 & 13 & 18 & 12 & 15 \\
\hline LV & 24 & 15 & 45 & 9 & 17 \\
\hline PL & 38 & 40 & 26 & 13 & 38 \\
\hline RO & 13 & 2 & 9 & 2 & 13 \\
\hline SK & 4 & 27 & 31 & 20 & 23 \\
\hline SI & 49 & 30 & 30 & 21 & 15 \\
\hline HU & 19 & 2011 & & 13 & 13 \\
\hline
\end{tabular}

Source: Author's work based on: World Investment Report 2011. Non-Equity Modes of International Production and Development. UNCTAD, Geneva 2011.

From 2006 to 2010 the largest number of mergers and seizures was carried out in the world in 2007. Sale of shares in companies based on these grounds equaled $60 \%$ of general transactions in the world. Since 2008 there have been observed decrease in share of this form of foreign direct investments, from 51\% to 33\% in 2009 and their slight growth in 2010 up to $37 \%$. In the Central \& Eastern Europe countries, sale of shares in companies in form of mergers and seizures in 2006 reached nearly $5 \%$ of transactions, in $2008-4.3 \%$ and in 2010 just $3.12 \%$. Purchase of shares was much lower that is $0.80 \%$ of general number of transactions i.e. mergers and seizures. From among this group of countries the highest sale level concerned: Czech Republic, and at the end of the examined period (2009-2010), also Poland and Hungary.

Table 7. Number of cross-border M\&As, 2006- 2010

\begin{tabular}{|c|c|c|c|c|c|}
\hline & 2006 & 2007 & 2008 & 2009 & 2010 \\
\hline \multicolumn{7}{|c|}{ Net sales } \\
\hline World & 5747 & 7018 & 6425 & 4239 & 5405 \\
\hline EU & 2354 & 2717 & 2419 & 1344 & 1780 \\
\hline CEE & $\mathbf{2 7 8}$ & $\mathbf{2 8 4}$ & $\mathbf{2 7 8}$ & $\mathbf{1 3 8}$ & $\mathbf{1 6 9}$ \\
\hline USA & 1056 & 1297 & 1117 & 710 & 884 \\
\hline \multicolumn{7}{|c|}{ Net purchases } \\
\hline World & 5747 & 7018 & 6425 & 4239 & 5405 \\
\hline EU & 2216 & 2782 & 2548 & 1328 & 1723 \\
\hline CEE & $\mathbf{5 3}$ & $\mathbf{7 8}$ & $\mathbf{8 8}$ & $\mathbf{3 4}$ & $\mathbf{6 6}$ \\
\hline USA & 1063 & 1241 & 1085 & 582 & 879 \\
\hline
\end{tabular}

Source: Author's work based on: World Investment Report 2011. Non-Equity Modes of International Production and Development. UNCTAD, Geneva 2011.

It also should be mentioned that another effect of the economic crisis, apart from lower number of mergers and seizures, there was also a decrease in value of transactions in the world and in the region as well.

In member countries from the Central \& Eastern Europe region values of transactions reached small amounts i.e. USD 67 million in 2009 in case of purchase of shares, and USD 10 million in 2008. Sale of shares enabling mergers and seizures of companies by the Central \& Eastern Europe countries reached USD 42 million in 2009 and the smallest amounts exceeded USD 10 million only in 2010.

\section{Conclusions}

International flow of the capital including the FDI play a substantial role in the field economic systems of particular countries as well as the economy (a global economy). For this reason all countries trying to attract capital into their economies establish attractive conditions for investors. Also entrepreneurs, at a particular moment of their economic activity, make a decision on making their business international.

Worldwide crisis dated 2008 clearly affected the international capital flows in form of the foreign direct investments in the world and in member countries of the European Union and the Central \& Eastern Europe. Countries under examination suffered from effects of the crisis to a very varied extent which is evidenced by completed analysis of macroeconomic factors. Countries 
from the region under examination already know that their functioning in a group does not provide resistance to a crisis and moreover, the membership may appear to be a weakness.

One of effects of the crisis there was also a decrease in flows of the FDI in the world. Investors have become more careful and less susceptible to risk when seeing difficult situation in the world market. Interest in investments looking for a market went down as well as investments looking for resources and increase in efficiency. From the other hand the crisis enforced restructuring actions and enforced better solutions. Nevertheless, investments could not be carried out because of decreased financial capabilities of the companies with limited financing from foreign and internal sources.

Despite inflow of the FDI decreased in the period from 2008 - 2009 and it was accelerating very slowly in many countries the following years their value is still lower by approx. $15 \%$ compared to average value from before the crisis. Cheap assets became an occasion for mergers however, the phenomenon in question is characterized by a serious disadvantage in a long term since it results in consolidation and a risk of monopolization. Moreover, large development disproportions among countries, including those from the Central \& Eastern Europe region, enforces need for restructuring, inflow of new technologies, production and management methods, hence, one could guess that there will be a potential for such investments.

Inflow of the foreign direct investments into the Central and Eastern Europe countries is necessary since it positively affects development and economic growth of such countries as well as it promotes increase in the productivity and quality of manufactured products and rendered services because of technology transfer and new management methods. From the other hand the economic crisis in many European Union countries increased the economic activity risk in the territory of such countries, including the old fifteen countries. Central and Eastern Europe countries may be presently deemed to be more stable and they may become serious beneficiaries of the foreign investments. They offer potential investors advantageous locations for their capitals and satisfy conditions which the investors expect.

\section{REFERENCES}

[1] IMF (1993), Balance of Payment Manual, 5th edition, Washington D.C.: IMF Publications.

[2] UNCTAD (1998), World Investment Report, New York: United Nation

[3] Misala J. (2001), Współczesne teorie wymiany międzynarodowej i zagranicznej polityki ekonomicznej, SGH, Warszawa

[4] Meyer K.E, Peng M.W. (2005), Probing theoretically into
Central and Eastern Europe: transactions, resources, and institutions, ,Journal of International Business Studies”, $\mathrm{nr}$ 36.

[5] Dunning J.H., (1977), Trade, location of economic activity and the MNE: A search for an eclectic approach [w:] The international allocation of economic activity, red. B. Ohlin, P.O. Hesselborn, P.M. Wijkman, Holmes and Meier, New York.

[6] Dunning J.H., (1980), Toward an eclectic theory of international production: Some empirical tests, ,Journal of International Business Studies", nr 11.

[7] Narula R., Dunning J.H., (2000), Industrial development, globalization and multinational enterprises: New realities for developing countries, „Oxford Development Studies”, nr 28.

[8] Mudambi R., Navarra P., (2002), Institutions and international business: A theoretical overview, ,International Business Review", nr 11.

[9] Rugman A.M., Verbeke A., (2001), Multinational enterprises and public policy [w:] Oxford handbook of international business, red. A.M. Rugman, T.L. Brewer, Oxford University Press, Oxford.

[10] Peng M.W., (2000), Business strategies in transition economies, Sage, Thousand Oaks.

[11] Beyfuß J. (1996). Erfahrungen deutscher Auslandsinvestoren in Reformländern Mittel - und Osteuropas, Köln

[12] Nunnenkamp P., Spatz J. (2002). Determinants of FDI in developing countries: has globalization changed the rules of the game? Transnacional Corporations, vol. 11.

[13] Holland D., Sass M., Benacek V., Gronicki M. (2000). The determinants and impact of FDI in central and eastern Europe: a comparison of survey and econometric evidence. Transnational Corporations, vol. 9.

[14] Campos N.F., Kinoshita Y. (2003). Why does FDI go where it goes? New evidence from the transition economies. IMF Working Paper, IMF Institute

[15] Garibaldi P., Mora N., Sahay R., Zettelmeyer J.(2001). What moves capital to transition Economies, IMF Staff Papers, vol 48, Special Issue, International Monetary Found.

[16] Carstensen, K., Toubal F. (2004). Foreign Direct Investment in Central and Eastern European Countries: A Dynamic Panel Analysis. Journal of Comparative Economics 32.

[17] Disdier, A., Mayer T. (2004). How Different Is Eastern Europe? Structure and Determinants of Location Choices by French Firms in Eastern and Western Europe, Journal of Comparative Economics 32.

[18] Kuźniar R. (pod red.) (2011) Kryzys a pozycja międzynarodowa Zachodu, Scholar, Warszawa.

[19] Bamber B., Kiciński W. (1990). Joint ventures $w$ krajach Europy Środkowej i Wschodniej, Handel Zagraniczny, nr 10.

[20] Szromik A. (1993). Rynki Europy Wschodniej w oczach niemieckich przedsiębiorstw, Fundacja im. Friedricha Eberta, Warszawa.

[21] Brownell G. (2010), Emerging from crisis, fDi Magazine. 